\title{
Preliminary Report on Early Settlements and Archaeological Materials from Lindi Rural District, Lindi Region, Southeastern Tanzania
}

\author{
Charles Bernard Saanane \\ Department of Archaeology and Heritage, College of Humanities, University of Dar Es Salaam, Dar Es salaam, \\ Tanzania \\ Email: csaanane@yahoo.co.uk
}

Received 21 February 2016; accepted 16 May 2016; published 19 May 2016

Copyright (C) 2016 by authors and Scientific Research Publishing Inc.

This work is licensed under the Creative Commons Attribution International License (CC BY). http://creativecommons.org/licenses/by/4.0/

(c) (i) Open Access

\section{Abstract}

This paper presents a preliminary report based on a reconnaissance survey so as to create the basis for further archaeological research works. The reconnaissance was conducted along areas in Mipingo ward north of Lindi town in Lindi Rural district, Lindi Region, Southeastern Tanzania. The reconnaissance work's main objective was to pinpoint Iron Working, Neolithic and stone industrial techno-complexes (for example, Later Stone Age, Middle Stone Age and Sangoan-like traditions). Specifically, the reconnaissance works sought to identify cultural traditions such as Iron Working, Neolithic as well as Stone Age sequences/facies; to document other cultural heritage resources (movable and immovable, fauna or flora) in the areas; and later on, as a long-term goal after a fully-fledged research is done (after several years of works), to undertake community involvement for conservation as well as carry out presentation of the cultural heritage assets in form of a satellite museum/museums to be linked with the University of Dares Salaam Museum under the Department of Archaeology and Heritage. Normal archaeological survey strategies were employed in the area. The spotted materials were collected and GPS locations were noted. The area showed some potential archaeological remains that merit intensive archaeological research works. Such archaeological materials include ruins, tombs, stone tools and two pieces of pottery. In terms of cultural traditions, there is evidence pointing to Stone Age people from early Stone Age represented by Acheulian Industrial techno-complex followed by Middle Stone Age and Later Stone Age people. Furthermore, though two pieces of pottery were recovered, further intensive works may help to justify Iron Working people lived there. Moreover, remains of a house foundation reported to have been a store of slaves implying to the fact that slavery was not only practiced in Bagamoyo, Zanzibar and other places already reported in Tanzania, but also as far as Southeastern Tanzania, in particular, at Mchinga II and Mchinga II village in Lindi region. The tomb at Namihodi hamlet, Mchinga I village and graves close to the house foundation at Mchinga II villages 
also justify stay of foreign people, possibly Persians and/or Arabs. Presence of remains of Mosques at Mchinga I and Mchinga II implied that Islam was practiced there about three hundred thousand years ago, a pattern firmly established at other places along coastal Tanzania areas like Kaole, Bagamoyo, Kunduchi, Mbweni, Kilwa and many more places. In addition, indigenous people still undertake their rituals in the area as shown at Mchinga II village and Kilangala A village. The reported ruins at Mchinga I, Mchinga II and Kilangala villages need further research so as to get further insights and undertake community conservation as desired by the proponent.

\section{Keywords}

Dinosaur, Acheulian Industrial Techno-Complex, Middle Stone Age, Later Stone Age, Sangoan Like Traditions, Ruins, Tombs, Fauna and Flora

\section{Introduction}

\subsection{Background Information}

This paper presents a preliminary report based on a reconnaissance survey in Southeastern Tanzania so as to create the basis for further archaeological research works. The reconnaissance was conducted along areas in Mipingo ward north of Lindi town in Lindi Rural district, Lindi Region, Southeastern Tanzania.

Southeastern areas in Tanzania have offered great cultural heritage resources. However, there are some pockets that are not scientifically investigated. There are notable cultural heritage sites. For example, at Tawa Pondo near Nandembo in Matumbi Hills, Kilwa District, a series of hominin footprints on roof of caves were found [1]. Palaeontological excavations at the locality yielded a substantial number of skull remains that were exported to Europe [1].

Geological and Palaeontological Information

The geology of southeastern Tanzania has very old deposits with Cenozoic deposits covering the large area. The said pattern was justified by later works. For example, Nachingwea Technical Report of 2009, revealed that,

“...Proterozoic Mozambique Belt (MB) in southeastern Tanzania. The MB comprises a dominantly north-south trending domain of highly deformed and metamorphosed rocks which formed during oblique collision of east and west Gondwana and are part of the Pan-African Orogenic System. The MB includes lithologies that have been affected by both the Usagaran $(1.8 \mathrm{Ga}$ to $2.0 \mathrm{Ga})$ and the Pan-African $(650 \mathrm{Ma}$ to $580 \mathrm{Ma}$ ) orogenic events. Throughout the $\mathrm{MB}$, formation ages of around $1.8 \mathrm{Ga}$ have been reported, consistent with a late Proterozoic (i.e., Usagaran) pre-collisional basement age...".

Tendaguru, situated almost 60 kilometres from the Indian Ocean, is a hill elevated at almost 350 metres above sea level in Lindi District, Lindi region. The site yielded the most superb dinosaur from Tendaguru Series known as Brachiosaurus brancai [2]-[18]. It is the biggest dinosaur to have had lived in Africa and has the following features: a long neck, long forelimbs, 22.5 metres long and 12.5 metres high thereby displaying a figure like that of a giraffe with a relatively small head and lightly built by largely expanded cranial openings [13]-[15] [18]. Furthermore, two groups of Ornithiscians were recovered from Tendaguru: the first represents huge quadruped armoured forms and the second represents bipedal non-armoured forms [9] [10] [15] [16] [18]. The former is represented by Kentrurosaurus aethiopicus [11] and the latter is represented by Ornithopod lettowvorbecki [18], but was later on renamed as Dysalotosaurus lettowvorbecki by Jannensch [18].

Other vertebrate remains recovered from Tendaguru Series include the following: fish remains Lepidotus minor and Elasmobranchian teeth as well as fish spines [9]. No avian remains were recovered from Tendaguru localities but over 150 isolated fauna specimens characteristics of Pterosaur were recovered and represent three genera, namely, Rhamphorrhychus tendagurense, Pterodactylus amingi and Pterodactylus maximus [18]. Besides the fact that evolution of African mammals is barely known, a mammalian jaw fragment without teeth was recovered from Upper Saurian Beds of Tendaguru Series [4]. It was assigned the name Brancatherulum tendagurense by [5], but further analyses led to assignment into families either Paurodontidae or Paramuridae [8] [18].

In addition, Tendaguru, the mentioned dinosaur locality is not very far from Nachingwea, close to Tunduru at Msamara hills, Rynchosaurian remains (from Cretaceous deposits) were recovered in German colonial times [18]. 


\section{Stone Age Cultures}

There are several Middle Stone Age (MSA) occurrences along the Southeastern coastal areas of Tanzania. Most stone tool types, in scatters, representing the cultural tradition include triangular points as well as Leva lour flakes. They have been observed along the following areas: north-eastern corner of Kilwa Island; Mapata area along mainland Kilwa; woodland areas along Mbwemkuru River as well as across the Indian Ocean shore areas; Mchinga woodland area; and open areas around Mikindani [1]. Other MSA localities include Kipili (80 kilometres South of Lindi along Masasi road and Kimbilimu hill along the road from Milola to Nangaru (Lindi district). The latter locality yielded bifacial tools, Levalloisian cores, points and scrapers at Mandawa village; Chilotwa area; and Kiliamanda [1] (Figure 1, Figure 2).

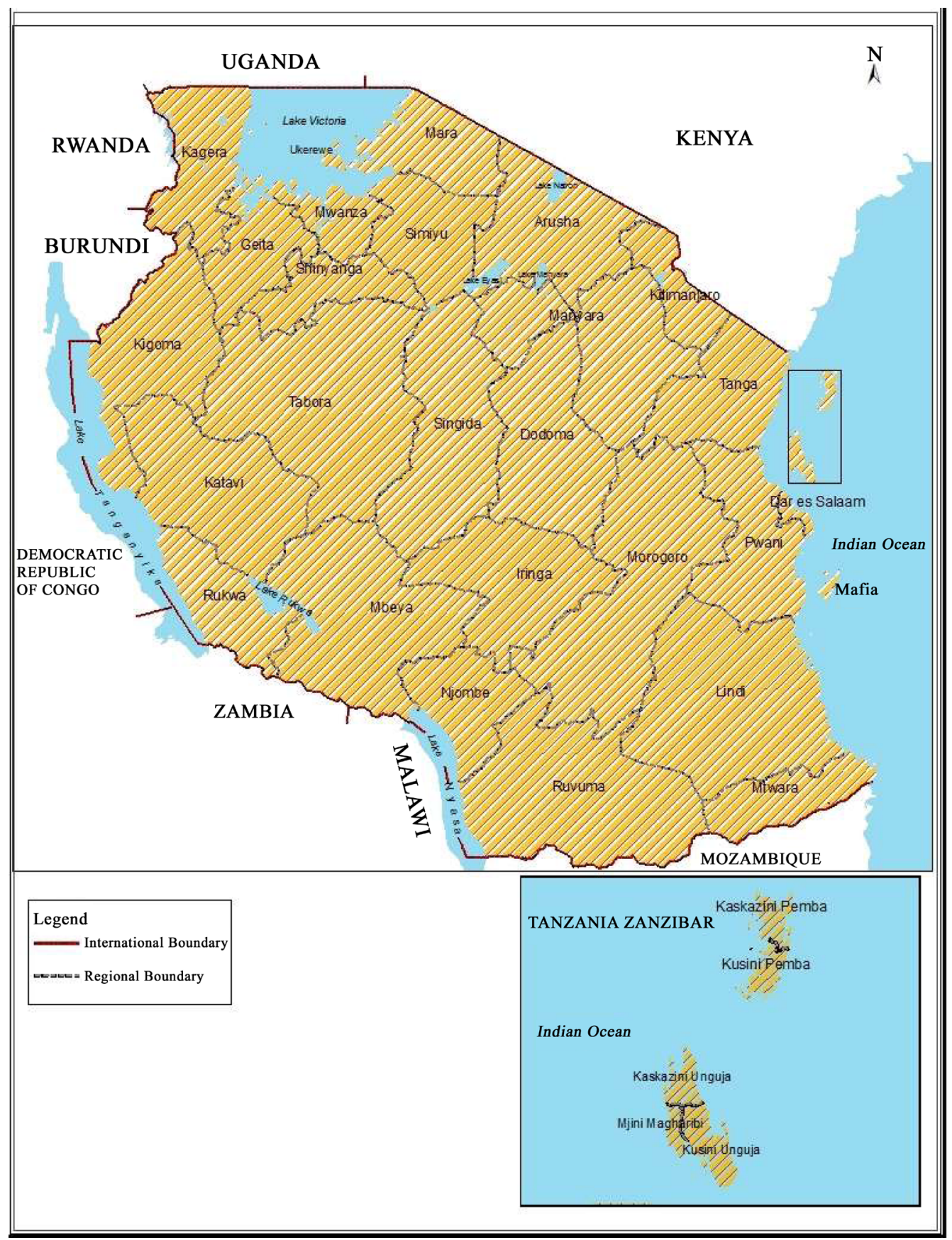

Figure 1. Southeastern Tanzania coastal areas. 


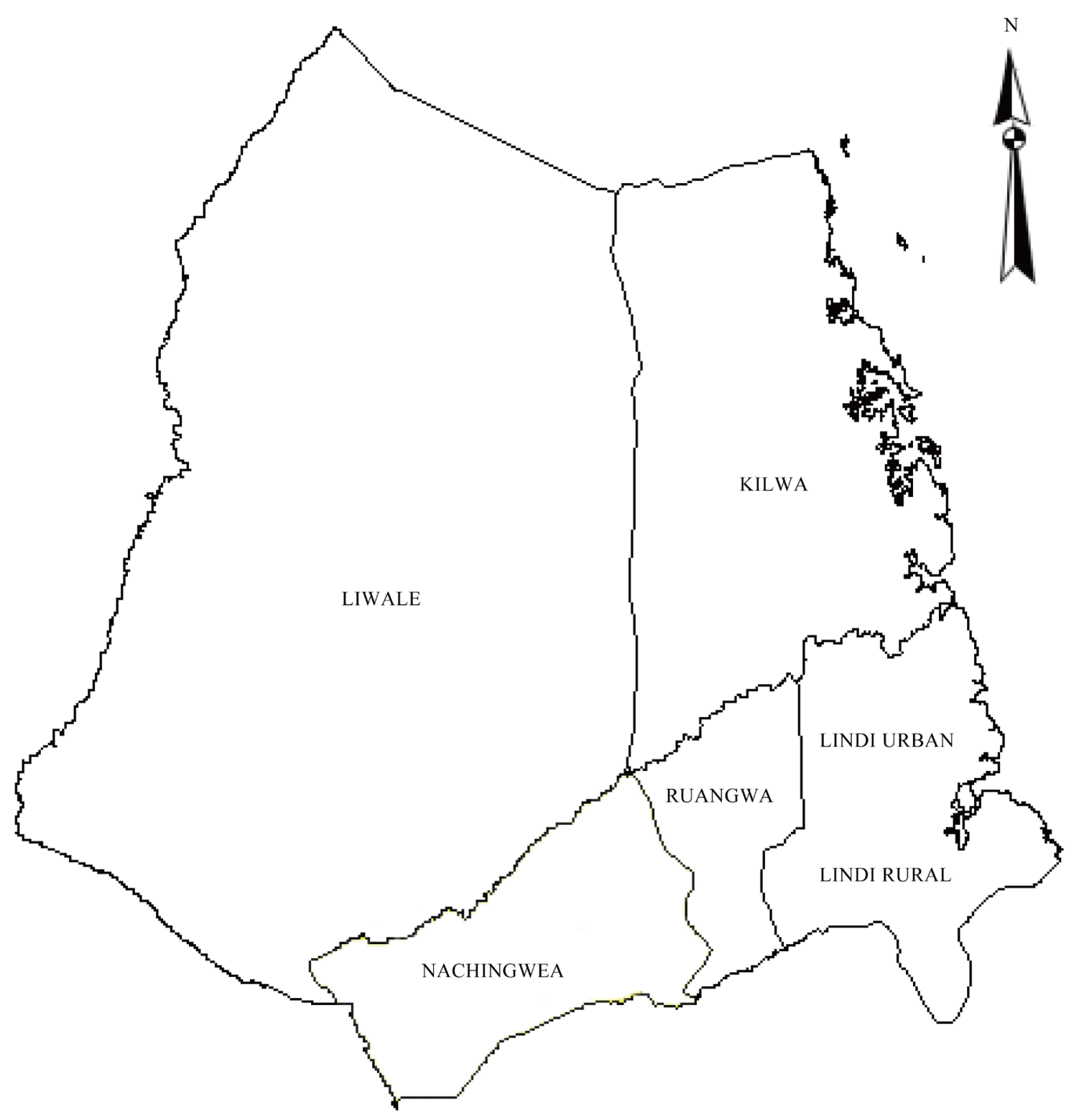

Figure 2. Map of Lindi Region.

Neolithic/Pastoral Neolithic

Neolithic/Pastoral Neolithic materials have been reported along the Rift Valley and Nile Valley including East African coastal areas and islands in the Indian Ocean. For example, Kansyore/Khartoum pottery has been recovered from Kilwa Island, while Nderit pottery has been reported from Mtwara and Kilwa Island [19]. The most widespread were Narosura pottery remains recovered at Tendaguru dinosaur site [1], Rufiji Delta area and Kilwa Island [19]. Pottery specimens related to some Nile and Rift Valley including Narosura and Ileret/Khartoum Neolithic were recovered in a site in catchments interior of Rufiji area, about 150 kilometres from the coast [19].

Stone tools have been recovered in coastal areas dating in the same time bracket. They are small quartz nodules split by bipolar on an anvil technique accompanied with residual fragments without secondary modification.

Pre-Iron Working Traditions

Southern coast of Tanzania has yielded Pre-Iron Working traditions represented by pottery making technolo- 
gy [19]. They are stone working settled traditions such that pottery materials of the period are called Pre- Ironworking wares [19] [20]. They were recorded from Mnaida hill (Mikindani) to the hinterland at Kitere area [see also Figure 1] [19] [20]. The recovered materials have been named as Mnaida tradition, dated around the $3^{\text {rd }}$ century Before Christ (245 \pm 35 ) [20]. Also chipped stones, cores and flakes were recovered at Mnangole and Mtwara areas [20].

\section{Iron Working Tradition}

Research works in areas notably, north of Rufiji Delta and in all offshore islands recovered concentrations of Early Iron Working sites dated from about 200 BC to about A.D. 500. For example, potsherds of Iron Working sites have been recovered from lower levels of Unguja Kuu site, mainly, made of Triangular Incised Ware tradition [19]. Other localities with the same traditions include Makunduchi and Machaga in Unguja, Zanzibar [19]. In Kilwa Island, an Early Iron Working site yielded potsherds with large quantities of iron smelting debris, a few metres south of Husuni Kubwa monument [19] [20].

Iron Working sites are characterized by ceramics, while some are associated with artifacts such as glass beads, imported metal (Copper) and pieces of gum copal [19] [20]. The said associated materials give evidence for trade, while some sites are associated with iron that was smelt by indigenous people for foraging and/or export [19] [20].

In addition, the littoral coast is characterized by Swahili Culture identified by settlements with distinctive architectural patterns that include tombs (some with pillars), houses, mosques and other houses built of coral rag as well as those built of mud and wattle [19]. It is reported that the Swahili were involved in local and foreign trade [19] [20]. Most of such sites are found at towns and villages such as Kilwa Kisiwani, Kilwa Masoko, Kisiju, Bagamoyo, Kaole, Kunduchi and Mbweni, to mention a few [20].

In sum, Early Iron Working cultural tradition for the coast of Tanzania can be divided in three phases, starting from the earliest to the latest: Limbo/Urewe, Kwale and Mwangia. Limbo/Urewe dates ranges between 0 to A.D. 200, Kwale from A.D. 200 to 400 and Mwangia from A.D. 400 to 600 [19] [20].

\section{Historical Information}

Archaeological works focus on establishing and authenticating chronological frameworks of coastal communities from early times to recent times. Such works help to confirm or otherwise, historical information recovered from early travelers' chronicles, oral traditions and historical researches.

In [21] it was suggested that Islamic cultural history in East Africa was marked by the following three periods: the first period involved early settlements in coastal areas under the rule of Zanj; the second was marked by Shirazi people who set in formation of several settlement dynasties along the coast that were later on dominated by Portuguese; and the third period that succeeded the decline of Portuguese power and led to transformation of the Shirazi cultural pattern by having the Hadrami Shafii Islamic dominance. The latter period was marked by Asian Moslems who had begun to play a major role in bringing in Islamic sectarianism in its most acute form [21].

In 1856, during the end of reign of fifty years, the Muscat ruler, Sultan Seyyid Saidi reinforced his dominion over the Arab settled towns of the East African coast and moved his capital to Zanzibar, a port that had became the focal point of international trade between East Africa and the outside world [21]. Thus, Zanzibar became the main outlet of hinterland exports of slaves, ivory and gum-copal [21]. Encouragement of clove production stimulated direct trade links with European and North American countries that imported small arms as well as hardware and cloth [22].

In A.D. 1100, Arab migration with their influence from the nuclei of Shirazi culture (at places such as Mogadishu, Brava and Pate in Somalia as well as Lamu and Mombasa in Kenya) was carried further South in Tanzania to Pemba, Zanzibar, Mafia and Kilwa islands [21]. In East African coastal area, by the 14th century, there emerged a distinctive Islamic coastal civilization called Shirazi [20]. Actually, interactions between Bantu (indigenous people) and Persian as well as Arab settlers resulted into a Bantu-Islamic civilization [21].

In 1498, Portuguese found Kilwa in its decline but their occupation from 1505 to 1512 revamped its strength [21]. Abandonment and subsequent dismantle of Portuguese fort in Kilwa in 1512 did not alter the ancient dynasty and ancient trade, but later on, a steady propensity of Mozambique and at the end of the 16th century, progress of Mombasa as centres of trade by Portuguese, which created a progressive decline of ancient Kilwa [21].

\subsection{Significance of the Reconnaissance Works}

Southeastern Tanzania has cultural heritage resources potential for further palaeoanthropological research works 
that would culminate into establishment of cultural tourism sites. The reconnaissance along areas in Mipingo ward north of Lindi town in Lindi Rural district was conducted in order to uncover the following possible cultural traditions: Iron Working; Neolithic, Later Stone Age, Middle Stone Age and likely, Acheulian or Sangoan-like traditions. Thus, further archaeological investigation is desirous so as to add to already presented data along the Southeastern coast of Tanzania. The said areas are between 40 and 100 kilometres from the Indian sea shore and are not very far from famous dinosaur locality, Tendaguru. Furthermore, results from extended archaeological research works would add to archaeological data and refine old-held views that only North-Central Tanzania is the limit of Stone Age Cultural traditions.

\subsection{Objectives}

\subsubsection{Main Objective}

The Main Objective of the reconnaissance work was to pinpoint Iron Working, Neolithic and stone too industrial techno-complexes (for example, Later Stone Age, Middle Stone Age and Sangoan-like traditions).

\subsubsection{Specific Objectives}

The reconnaissance work had the following specific objectives:

- To identify cultural traditions such as Iron Working, Neolithic as well as Stone Age sequences/facies;

- To document other cultural heritage resources (movable and immovable, fauna or flaura) in the areas;

- Later on, as a long-term goal after a fully-fledged research is done (after several years of works), to undertake community involvement for conservation as well as carry out presentation of the cultural heritage assets in form of a satellite museum/museums to be linked with the University of Dares Salaam Museum under the Department of Archaeology and Heritage.

\section{Methodology}

\subsection{Study Area}

The reconnaissance work was undertaken at Mipingo village in Mipingo ward along Lipogiro plateau including its close by areas like Mchinga in Lindi Rural District, Lindi region (Figure 1).

\subsection{Data Collection Methods}

1) Archaeological studies

Archaeological surveys were carried out. Survey spots were marked on topographic maps and their Global Positioning System (GPS) coordinates were recorded. Such pieces of information will be used to relocate the sites. In addition, key informant interviews were carried out at Mchinga I and Mchinga II villages.

Archaeological localities were documented following a standardized 13 point protocol. Data recorded included GPS coordinates, photographic documentation of each locality and find and field notes on current geography. Localities were recorded in a Geographical Information System (GIS) set up for localities. Artefacts (like pottery, slag, tuyeres and so on), lithic finds and other artefacts were only collected from localities that were established using the protocol already mentioned and were further be documented following a standardized ten point protocol. Documentation included GPS coordinates, photographic record as well as preliminary notes as to identification (either taxonomic or in terms of lithic industry), preservation and taphonomic features. Collected specimens were identified and sorted to extent feasible in the field. Parallel hard copy as well as electronic records was maintained for both specimens and localities. Excavations involved establishing 1 by 2 metres grids and collecting pottery, slag, tuyere, bone as well as lithic materials within the grids and noting surface the faunal specimen was facing up when it was collected.

\section{Results and Discussion}

\section{Results from key informant interviews}

Through key informant interviews with elderly persons in Lindi Rural District that include the following: Mchinga I and Mchinga II villages, Lindi Rural District it was revealed that Arabs settled in Mchinga area several hundred years ago, about three hundred years ago. They built houses, a mosque and there are graves of people who lived at that time in the area. At Mchinga I village, remains of an ancient mosque foundation and 
remains of a house foundation for storing slaves reported by informants to have had been built 300 years ago were spotted (Figure 1) [see Annex I for GPS location]. Also close to remains of the ancient mosque there are graves of people who lived at that time (Figure 3).

In addition, at Mchinga II village, there are remains of a house foundation (Figure 4). Informants reported that there was a house used for keeping slaves at that time, around 300 years ago.

The team was informed about people's traditional worship (rituals) practices in the area. People in Mchinga I and Mchinga II villages undertake rituals for solving their social problems. For example, people from the two villages converge at such a place to carry out rituals for rain-making at a locality within the ocean shore known as Nantamwa (Figure 5). Also, they reported that such traditional rituals are conducted when there are other

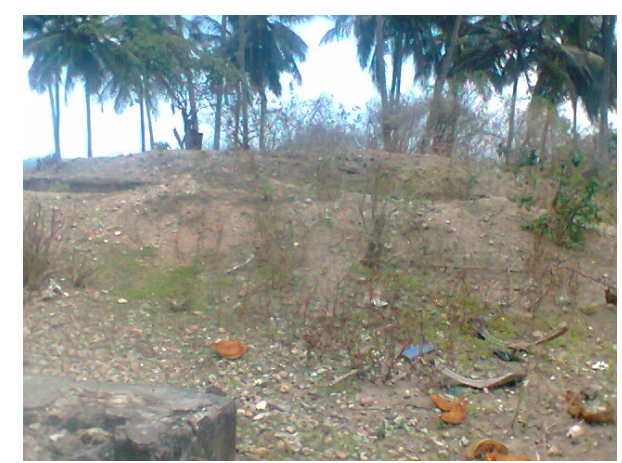

Figure 3. Remains/foundation of a mosque built 300 years ago and graves, Mchinga II village.

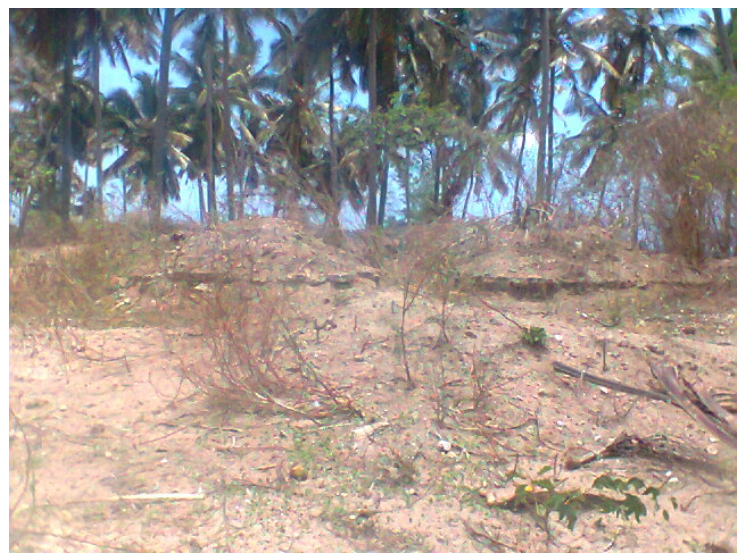

Figure 4. Remains of a foundation of a store for slaves and other business materials at Mchinga II village.

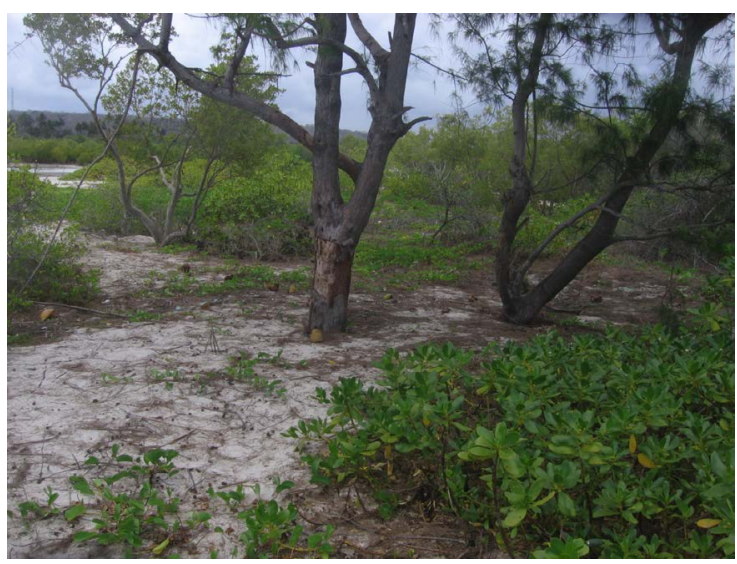

Figure 5. Nantamwa site for traditional rituals at Mchinga II village. 
problems like invasion by wild animals. Several years ago, wild animals like lions invaded villages and killed people. Thus, in order to be free from such a problem, diviners carried out traditional rituals to solve the problems and they said they succeeded. The place has no special structure but key informants reported that formerly there were many trees around but beach erosion has caused loss to such land and vegetation.

At Kilangala A village, informants reported of well located at Mtunduka near Luwawa forest reserve whereby people undertake traditional rituals. Furthermore, there was an old mosque built during Germany colonial times but has been destroyed recent road works. People are building another mosque within the vicinity. Almost 500 metres from the mosque at Miuta still in Kilangal A village, there are graves used by people with a place for rituals (Figure 6). A special traditional structure for such rituals can be seen under a tree close to the centre of the photograph (Figure 6).

The survey found a foundation of an old mosque with a dry well used for prayers and graves around at Namihodi hamlet in Mchinga I village believed to have been built 200 years ago (Figure 7). The well was on the right side of the mosque and graves can be located on far right to the mosque and well but they are covered with vegetation (Figure 7).

In addition, Namihodi hamlet in Mchinga I village has another locality with an old mosque believed to have been built 300 hundred years ago. There are remains of a foundation of the mosque (Figure 8) but people took some materials to build the current Friday mosque at Mchinga I village.

Furthermore, it was disclosed by informants that Namihodi hamlet has graves dating almost 300 years ago

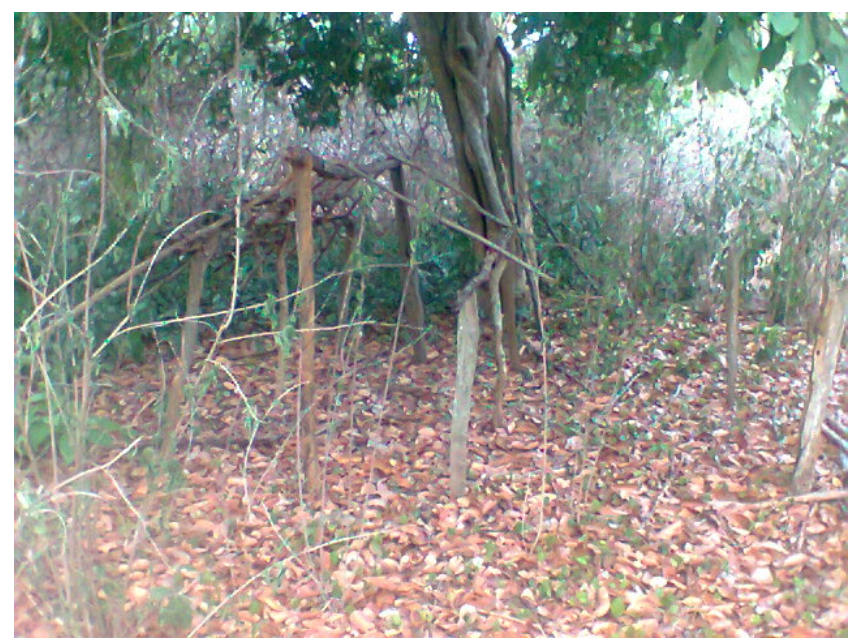

Figure 6. Structure for traditional rituals at Miuta, Kilangala A village.

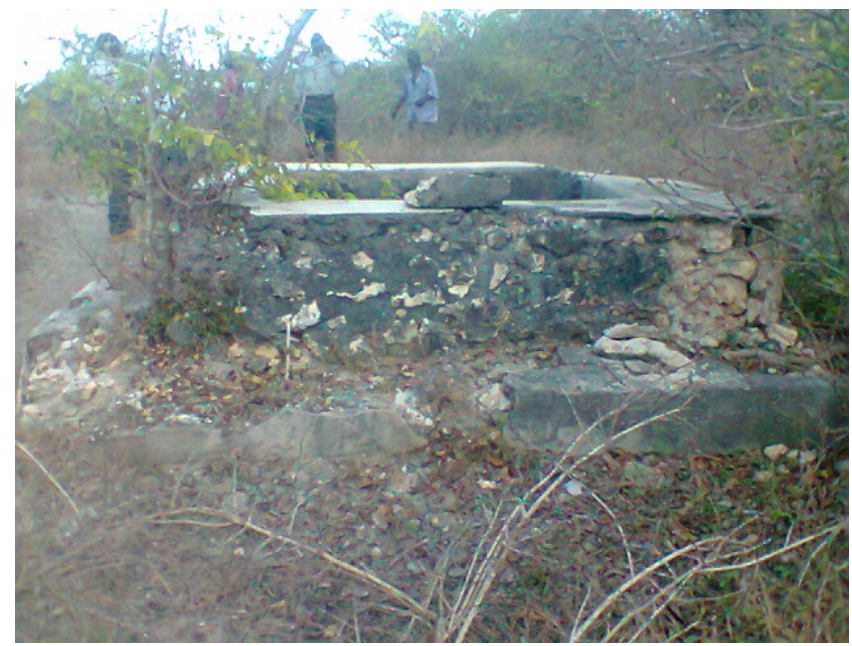

Figure 7. Remains of an old mosque with a dry well at Namihodi hamlet, Mchinga I village. 
In Figure 9, they are believed to be graves of Arabs who settled in the area. The grave as can be seen in Figure 8 that shows almost similar structures found along the coastal part of Tanzania, for example, at Kaole in Bagamoyo (Coast region), Mbweni in Kinondoni district, Dar es Salaam region and several other places dating a few centuries ago.

Also a house foundation with fallen over columns as well as other parts almost 150 metres away from the graves was spotted (Figure 10). It could have been built by Europeans as the columns show but further investi-

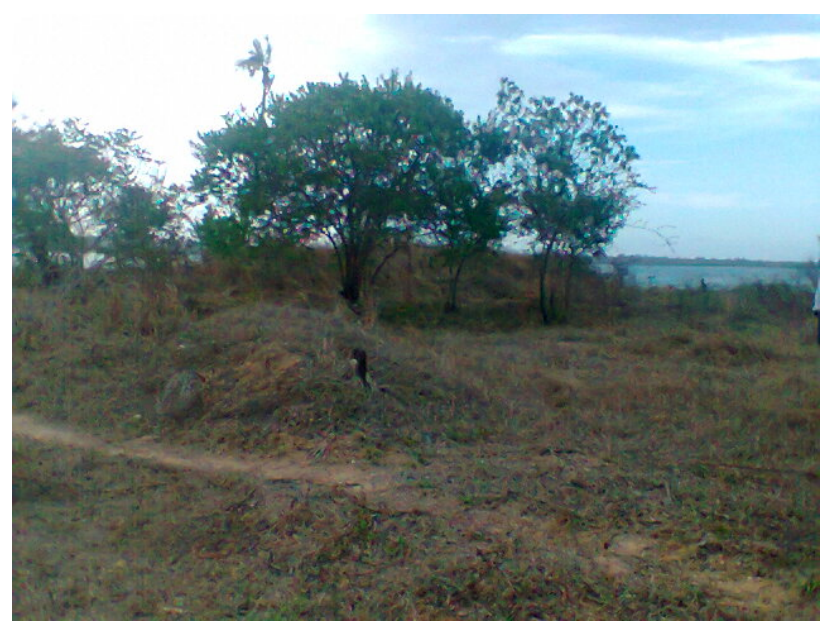

Figure 8. Remains of a mosque foundation built almost 300 years ago.

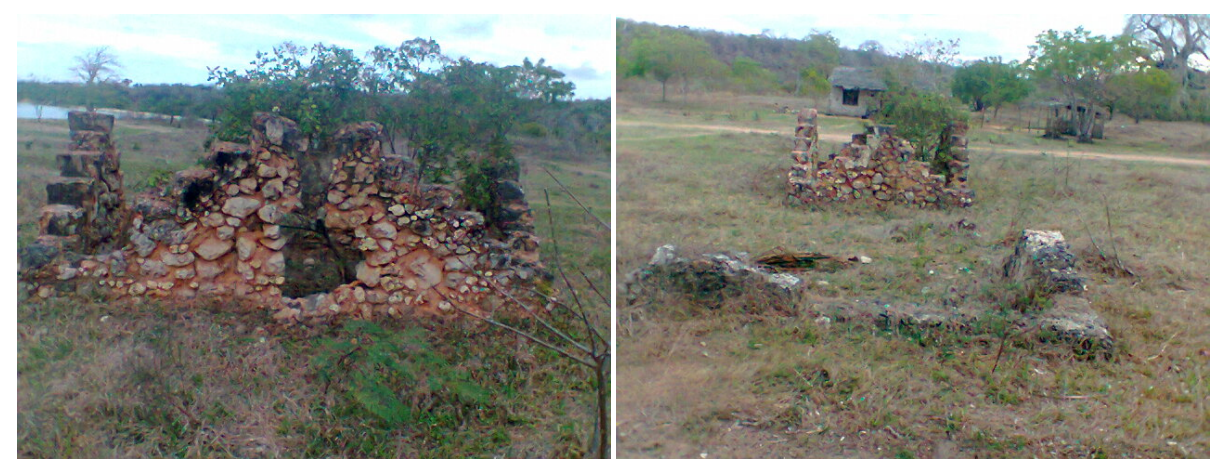

Figure 9. Graves at Namihodi hamlet.

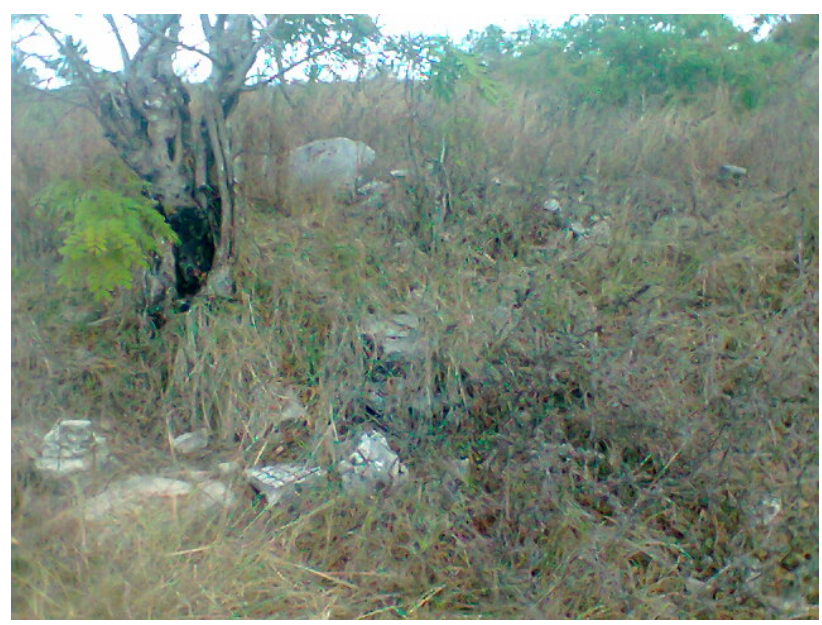

Figure 10. Remains of a house at Namihodi hamlet, Mchinga I village. 
gation needs to be done to authenticate those responsible for the said structure. Informants were unsure of builders, whether Arabs or Europeans.

Furthermore, the team was shown another cultural heritage asset at Ngande Kubwa, a border between Namiohodi hamlet and Mkambi hamlet in Mchinga I village. At the said locality, very close to the main road to Lindi town, there are old graves covered in thicket as seen in (Figure 11).

\section{Archaeological Materials}

Stone tools were recovered during the reconnaissance work at Mipingo village, Mipingo ward in Lindi Rural District, Lindi region (Figures 12-14). They were recovered on surface and included materials that could belong to Acheulian industrial complex (Figure 12); Middle Stone Age (Figure 13) and Later Stone Age (Figure 14). Raw materials ranged from quartzites that dominated to sandstones.

However, while proceeding with the reconnaissance along Mipingo village but moving towards Mnyangara village and later on, wanted to reach Lipogiro plateau, stone tools were spotted on heaps of sand and gravel accumulated by construction workers from Lindi Rural District (see Figure 15). According to an informant, a driver with road works department, Lindi Rural District, they were mined four kilometers or so after Mnyangara village along Lipogiro plateau. The place is towards Tendaguru and the team could not travel beyond the point because heaps of sand were left on the road for a long distance at a place with no route to diverge. The place is along a flood area with deep black clay soils. The materials were reported to have been dug deep in the sub-surface. They represent an anvil, a chopper and flakes. Raw materials included quartzites that dominated in the collected specimens.

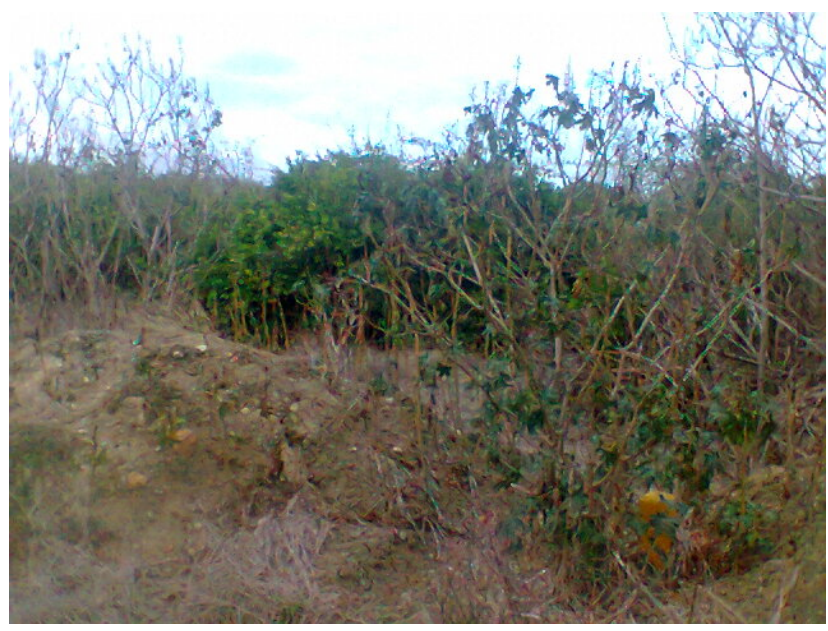

Figure 11. Graves at Ngande Kubwa, a border between Namihodi and Mkambi hamlets.

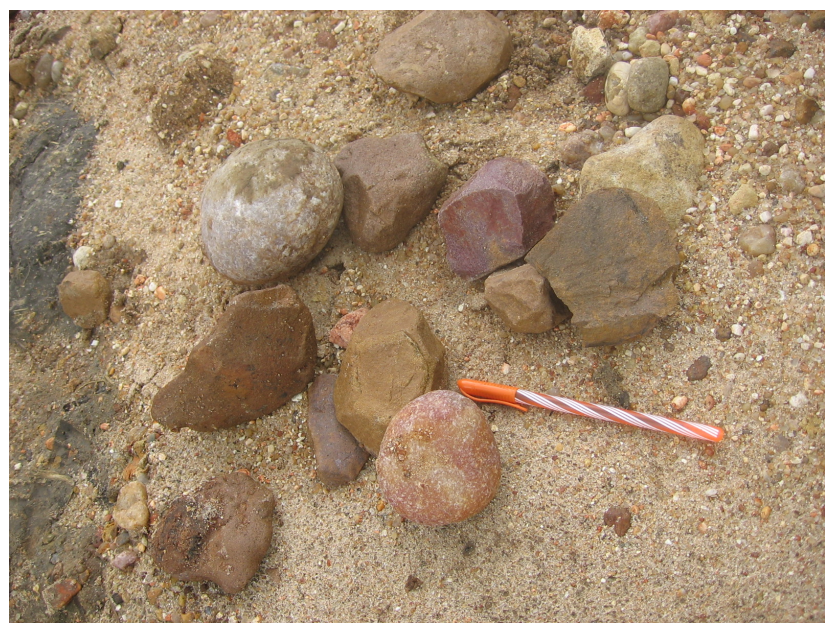

Figure 12. Acheulian Stone Tools. 

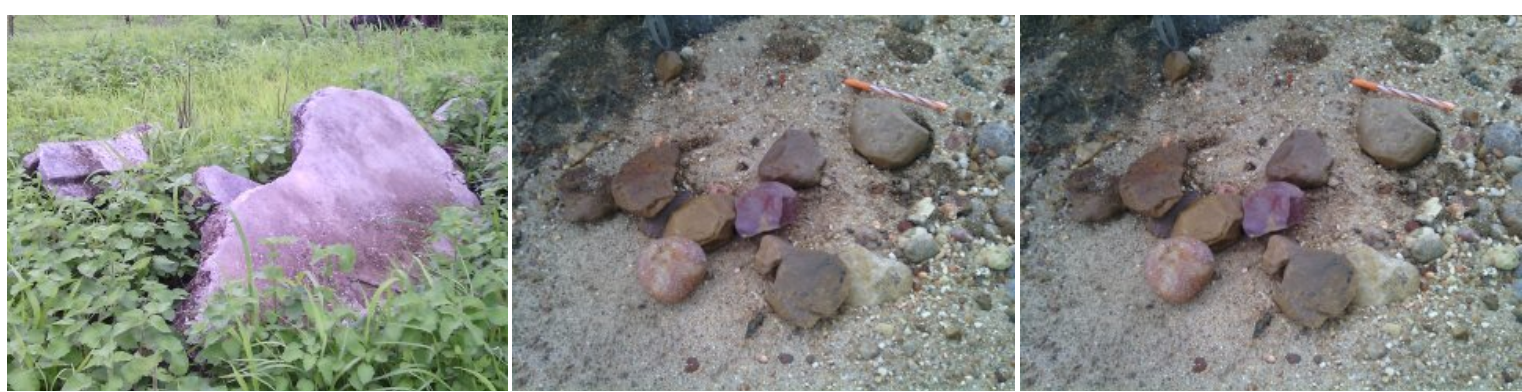

Figure 13. Middle stone artifacts.
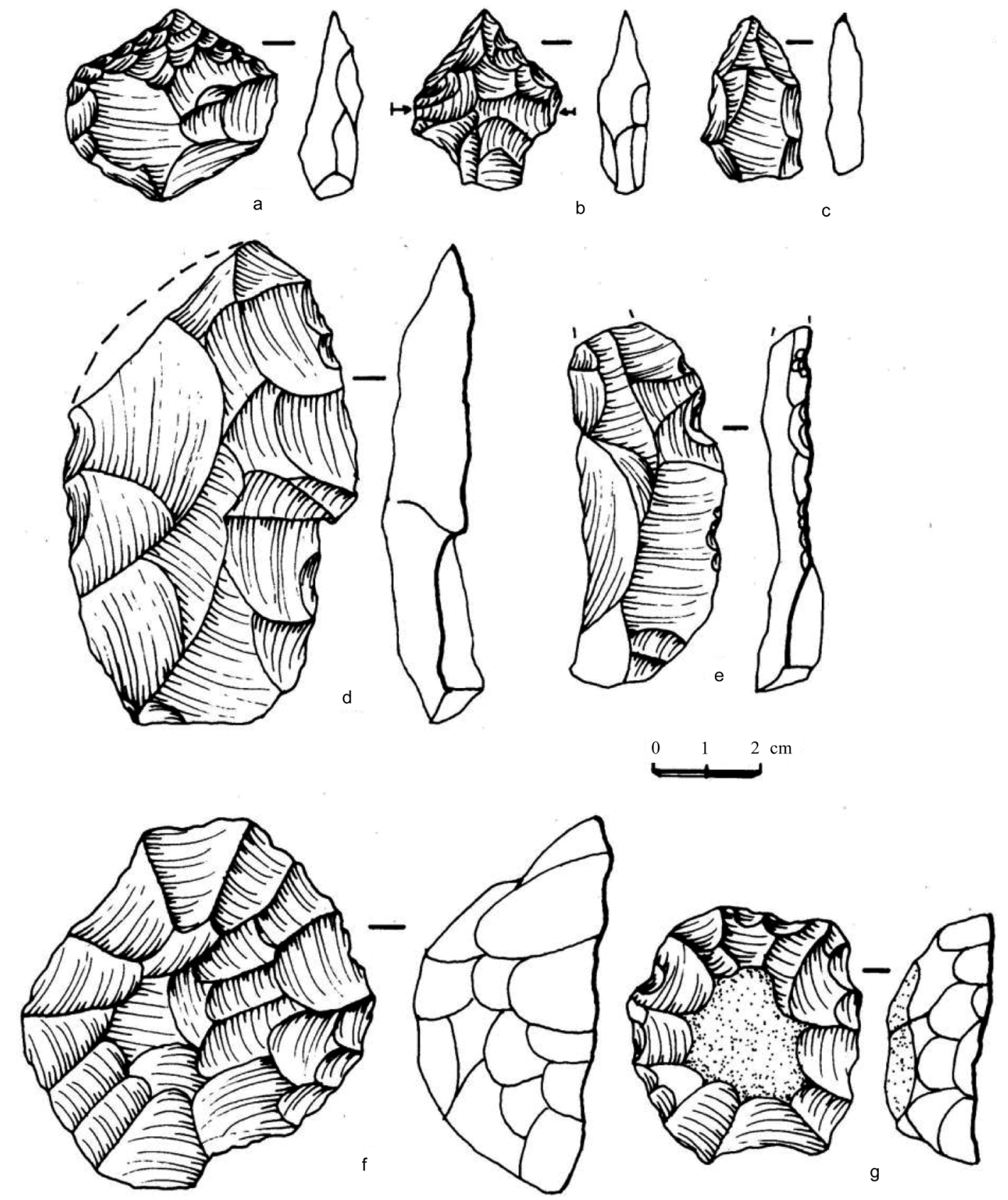

Figure 14. Later Stone Artifacts. Legend: Microlithic Points (a-c), Utilized blades (d-e), Discoidal scrapers (f-g). 

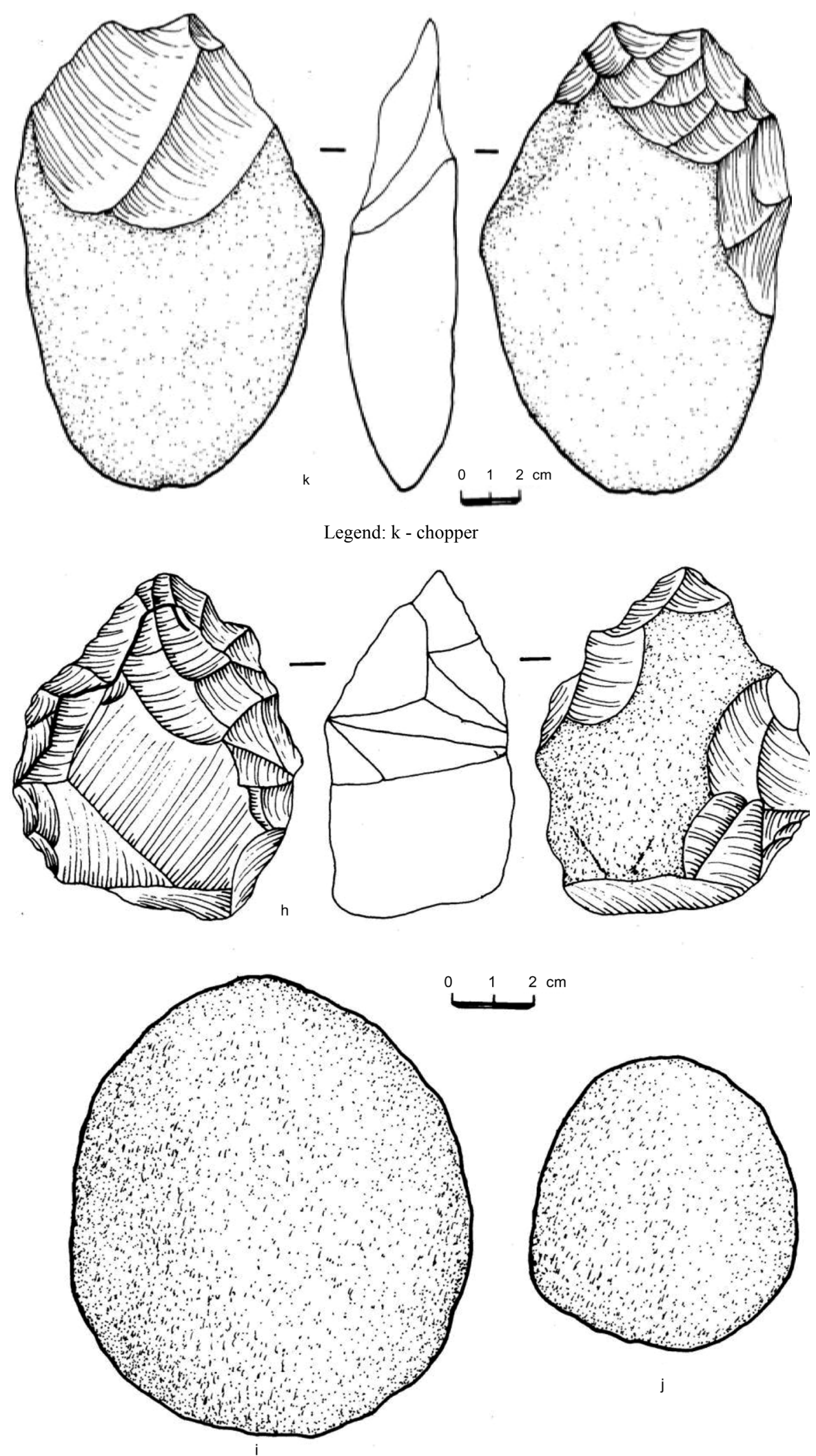

Legend: $\mathrm{h}$ - chopper; and I, j - Hammerstones

Figure 15. Acheulian stone tools. 
Recall, there is evidence of Middle Stone Age (MSA) occurrences along the Southeastern coastal areas of Tanzania represented by most stone tool types, in scatters, representing the cultural tradition include triangular points as well as Leva lour flakes. They were observed along the following areas: north-eastern corner of Kilwa Island; Mapata area along mainland Kilwa; woodland areas along Mbwemkuru River as well as across the Indian Ocean shore areas; Mchinga woodland area; and open areas around Mikindani [1]. Other MSA localities include Kipili ( 80 kilometres South of Lindi along Masasi road and Kimbilimu hill along the road from Milola to Nangaru (Lindi district). The latter locality yielded bifacial tools, Levalloisian cores, points and scrapers at Mandawa village; Chilotwa area; and Kiliamanda [1]. Thus, the presented findings show richness of cultural traditions in the areas.

\section{Pottery Materials}

Two broken pieces of pottery was recovered on surface in Mipingo village. One has a decoration along the neck and could belong to late Iron Working and the other one is undecorated. Such recovery also shows that there were later settlements in the areas after Stone Age people had had lived there several thousand years ago.

\section{Concluding Remarks and Future Prospects}

The reconnaissance revealed a lot of archaeological potential in terms of ruins, tombs, stone tools and a piece pottery. In terms of cultural traditions, there is evidence pointing to the following patterns: Stone Age people from early Stone Age represented by Acheulian Industrial techno-complex followed by Middle Stone Age and Later Stone Age people lived there. Furthermore, though two pieces of pottery were recovered, further intensive works may substantiate that Iron Working people lived there. Moreover, remains of a house foundation reported to have been a store of slaves point to the fact that slavery was not only practiced in Bagamoyo, Zanzibar and other places already reported, but also as far as Southeastern Tanzania, in particular, at Mchinga II and Mchinga II villages. The tomb at Namihodi hamlet, Mchinga I village and graves close to the house foundation at Mchinga II villages also justify stay of foreign people, possibly Persians and/or Arabs. Presence of remains of Mosques at Mchinga I and Mchinga II showed that Islam was practiced there about three hundred thousand years ago, a pattern firmly established at other places along coastal Tanzania areas like Kaole, Bagamoyo, Kunduchi, Mbweni, Kilwa and many more places. In addition, indigenous people still undertake their rituals in the area as shown at Mchinga II village and Kilangala A village.

The reported ruins at Mchinga I, Mchinga II and Kilangala villages need further research by, say, a master degree candidate so as to get further insights and undertake community conservation as desired by the proponent.

\section{Acknowledgements}

CS extends sincere gratitude to the Antiquities Division for the permit, African Archaeology Network, Regional Administrative Secretary for Lindi Region; District Executive Director, Lindi Rural District; Human Resources Officer, Lindi Rural District; Mr. Mudi, Lindi Cultural Officer (Lindi Rural); Ward Executive Officers for Mchinga and Mipingo wards; and Village Executive Officers for Mchinga I, Mchinga II, Moka and Mipingo villages. Mr. Said Kilindo, Technician, Department of Archaeology and Heritage is appreciated for his illustrations for stone tools.

\section{References}

[1] Morgan, J.C. (1939) The Machinga Caves (with a Note on Those on Songo-Songo Island and the Tawa-Pondo Cave). Tanganyika Notes and Records, 7, 59.

[2] Branca, W. (1914) Allegmeins uber die Nebergebnisse de Tandaguru-Expedition. Arch. Biont., 3, 67-70.

[3] Chami, F. and Kwekason, A. (2003) Neolithic Pottery Traditions from the Islands, Coast and the Interior of East Africa. African Archaeological Review, 20, 65-80. http://dx.doi.org/10.1023/A:1024426830217

[4] Branca, W. (1916) Ein Saugetier? Unterkiefer ausden Tandaguru-Schichten. Arch. Biont., 3, 137-140.

[5] Dietrich, W.O. (1927) Brancatherulum n.g., ein Proplacentalier aus dem obersten Jura des Tendaguru in DeutschOstafrika. Cbl. Geol. Palaeont., 10, 423-426.

[6] Galton, P.M. (1980) Avian-like tibiotarsi of Pterodactyloids (Reptilia: Pterosauria) from the Upper Jurassic of East Africa. Palaeontologische Zeitschrift, 54, 331-342. http://dx.doi.org/10.1007/BF02988135 
[7] Galton, P.M. (1980) Dryosaurus and Camptosaurus, Intercontigenera of Upper Jurassic Ornithopod Dinosaurs. Mémoires de la Société géologique de France, 139, 103-108.

[8] Heinrich, W.-D. (1991) Uber Brancatherulum tendagurense Dietrich 127 (Mammalia: Eupantotheria) uas dem Oberjura Tendaguru, Tansania. Eine vorlaufige Mitteilung. Mitteilungen aus dem Zoologischen Museum, 67, 97-104. http://dx.doi.org/10.1002/mmnz.19910670114

[9] Hennig, E. (1914) Die Invertebraten-Fauna der Saurierschichten am Tendaguru. Arch. Biont., 3, 155-185.

[10] Hennig, E. (1914) Die Fischreste unetr den Funden der Tendaguru-Expedition. Arch. Biont., 3, 291-312.

[11] Hennig, E. (1915) Kentrurosaurus aethiopicus; die Stegosaurier des Tendaguru. Sitzber. Ges. Naturf. Fr. Berlin, 1915, 219-247.

[12] Hennig, E. (1925) Kentrurosaurus aethiopicus; die Stegosaurier-Funde vom Tendaguru, Deutsch-Ostafrika. Palaeontographica, 7, 102-253.

[13] Jannensch, W. (1912) Verflauf und Ergebnisse der Expedition. Sitzber. Ges. Naturf. Fr, 1912, 124-137.

[14] Jannensch, W. (1914) Bericht uber den Verflauf der Tendaguru-Tendaguru. Arch. Biont., 3, 15-58.

[15] Jannensch, W. (1914) Ubersicht uber die Wirbeltierfauna der Tendaguru-Schichten, nebstiner kurzen Charakterisierung der neu aufgestellen Arten von Sauropoden. Arch. Biont., 3, 79-110.

[16] Leakey, L.S.B. (1925) Digging for Dinosaurs in Tanganyika. Illustrated London News, 166, 92-99.

[17] Magori, C C. and Saanane, C.B. (1998) Dinosaria wa Tendaguru. Dar es Salaam: E and D Publishers.

[18] Zils, W., Werner, C., Moritz, A. and Saanane, C. (1995) Tendaguru, the Most Famous Dinosaur Locality of Africa: Review, Survey and Future Prospects. Documenta Nature, 97, 1-41.

[19] Branca, W. (1914) Algemeines uber die Tendaguru-Expedition. Arch. Bionta., 3, 1-13.

[20] Kwekason, A.P. (2007) Pre-Iron Working Sedentary Communities on the Southern Coast of Tanzania. In Pwiti, G. and Chami, F., Eds., Studies in the African Past, Vol. 6, E and D Publishers, Dar Es Salaam, 20-40.

[21] Trimingham, J.S. (1975) The Arab Geographers and the East African Coast. In Chittick, N.H. and Roberts, R.J., Eds., East Africa and the Orient: Cultural Syntheses in Pre-Colonial Times, Holmes and Meier Publishers, Inc., New York, 115-146.

[22] Oliver, R. (1966) The Problem of Bantu Expansion. Journal of African History, 7, 361-376. http://dx.doi.org/10.1017/S0021853700006472 